\title{
Plague, an Extraordinary Tragedy
}

\author{
Nāsir Pūyān \\ ITIA (Iranian Translators \& Interpreters Association), Tehran, Iran \\ Email: nasser_pouyan@yahoo.com
}

How to cite this paper: Pūyān, N. (2017) Plague, an Extraordinary Tragedy. Open Access Library Journal, 4: e3643. https://doi.org/10.4236/oalib.1103643

Received: April 30, 2017

Accepted: August 8, 2017

Published: August 11, 2017

Copyright $\odot 2017$ by author and Open Access Library Inc.

This work is licensed under the Creative Commons Attribution International License (CC BY 4.0).

http://creativecommons.org/licenses/by/4.0/

(c) (†) Open Access

\begin{abstract}
The plague-otherwise called the Black Death or bubonic plague, a ghastly disease started in the east, possibly China, and spread through Europe quickly. Whole communities were wiped out and corpses littered on the streets as there was no one left to bury them. It was the greatest catastrophe of the Middle Ages, killing in its first wave, from 1347 to 1350 perhaps around 25 per cent of Europe's population. Plague physicians served as public servant during time of epidemic starting with Black Death of Europe in the fourteenth century. Almost simultaneous epidemics occurred across large portions of Asia and the Middle East including China and India. The same disease is thought to have returned to Europe every generation with varying degrees of intensity and mortality until 1700s. The remarkable later outbreaks include: 1) The Great Plague of the city of Florence in 1348. 2) The Great Plague of Milan in 1629. 3) The Great Plague of London in 1665-1666. 4) The Great Plague of Vienna in 1679. 5) The Great Plague of Marseille in 1720-1721. 6) The Plague in Moscow in 1771. The plague, one of the most devastating pandemics in human history, at the beginning of the nineteenth century was eradicated in Europe but it still survives in other parts of the world. They include Central and Oriental Africa, Madagascar, Asia, and The Americas including the United States. This paper presents a brief account of plague or Black Death pandemics in human history, resulting in mortality of around 200 million people, peaking in Europe during 1346-1353.
\end{abstract}

\section{Subject Areas}

Infectious Diseases

\section{Keywords}

Plague, Black Death, Florence, Milan, London, Vienna, Marseille, Moscow Plague Riot 


\section{Introduction}

For many centuries no one knew what caused illness. People believed that they had fallen ill because someone had ill-wished them or cast a spell on them. Witches caused disease by sticking pins into a wax image which nail clippings or hairs of the victim had mixed with wax. A comet in the sky caused a plague, and so did an eclipse of the sun or the moon. It was not until the eighteenth and nineteenth centuries that bacteria, then called germs, were studied, but viruses remained a mist until 20th century. Once the causes of disease had been identified, researchers could begin to eliminate them. One was improved public health, clean water, the disposal of rubbish and sewage which prevented the easy spread of diseases. The other was the discovery of antibiotic by Alexander Fleming in 1928 - substances that killed or seriously damaged the disease-carrying bacteria [1]. Not all bacteria are disease carriers, some are essential to life on the planet, but some are dangerous. The bacteria are easily transferred through the air because they are so small, but they can be destroyed by antiseptics. Bubonic plague, cholera, typhoid fever, diphtheria and food poisoning are just some of the ailments caused by bacteria (Figure 1).

During 1346-1353, the Black Death spread across Europe. The dreadful name, however, only came several centuries after its visitation chronicles and letters from the time described the terror wrought by the illness. In Florence, Petrarch anglicized version of Franco Petrarca (1304-1374), Italian poet and the founder of humanism, fleeing the plague of Milan, went to Padua [2]. He was sure that they would not be believed: "O happy posterity, who will not experience such abysmal woe and will look upon our testimony as a fable".

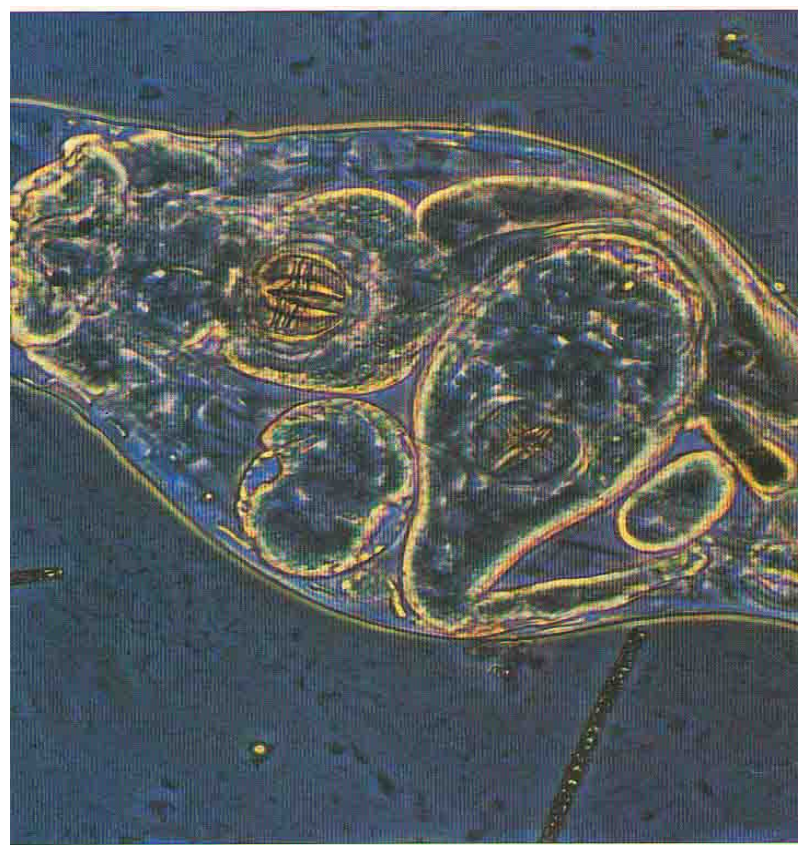

Figure 1. A bacterium viewed through an electron microscope. 
A Florentine chronicler relates that: "All the citizens did little else except to carry dead bodies to be buried... At every church they dug deep pits down to the water-table; and thus those who were poor who died during the night were bundled up quickly and thrown into the pit. In the morning when a large number of bodies were found in the pit, they took some earth and shoveled it down on top of them; and later others were placed on top of them and then another layer of earth, just as one makes lasagne with layers of pasta and cheese."

The chronicler Agnolo di Tura "the fat" relates from his Tuscan home town a remarkable similar account: “...in many places in Siena great pits were dug and piled deep with the multitude of dead... And there were also those who were so sparsely covered with earth that the dogs dragged them forth and devoured many bodies throughout the city."

The tragedy was extraordinary. In the course of just a few months 60 percent of Florence's population died from the plague, and probably the same proportion in Siena. In addition to the bald statistics, we come across profound personal tragedies: Petrarch lost to the Black Death his beloved Laura to whom he wrote his famous love poems; Di Tura tells us that "I ...buried my five children with my own hands."

\section{The Great Plagues}

Plague is a bacterial infection found mainly in rodents and their fleas. But via those fleas it can sometimes leap to humans. When it does, the outcome can behorrific, making plague outbreak the most notorious disease episodes in history.

The first well-documented pandemic was the Plague of Justinian, the emperor of Byzantine (527-565) which began in 541 A.D. named after the Byzantine emperor Justinian I, it killed up to 10,000 people a day in Constantinople (modern-day Istanbul, Turkey), according to ancient historians. Modern estimates suggest half of Europe's population was wiped out before the plague disappeared in the 700 s.

During the medieval period medical advances waned. Although prayers and incantations were still widely used to treat the sickness but religion lost much of its hold over medicine. Within this period, the plague or Black Death, disseminated Europe during the 14th century. Millions of people died from the disease which was caused by bacteria "pasteurella-pestis" and transmitted from rats to man by the bite of flea. The sickness frequently ran its entire course within 14 hours and terminated to death. The cause of disease and death were not known and the people were advised to flee from the stricken areas, causing further spread of the sickness. The epidemic gradually diminished in strength although it sprang up for the next three centuries. But, what has become known as the great plagues of Europe was actually only a subset of a much.

This epidemic appears to have been carried into the region from two opposing directions. It had been raging in Western Europe for many years, traveling East by trade routes. The Great Plague of London of 1665-1666, which is believed to 
have originated from the Netherlands in the 1650s, killed around 100,000 people, and was the first major epidemic in a series of outbreaks. In 1666 a severe plague raged in Cologne and the Rhine, which was prolonged until 1670 in the district. In the Netherlands there was plague in 1667-1669, but there are no definite notices of it after 1672. France saw its last plague epidemic in 1668. In 1675-1684, a new plague wave originated in the Ottoman Empire (Turkey and areas of the Balkans). It moved into North Africa, Bohemia, Poland, Hungary, Austria and Saxony, progressing generally northward. The island of Malta lost 11,000 persons in 1675.

The plague of Vienna in 1679 was very severe, causing at least 76,000 deaths. Other urban centers in this area of Europe had similar levels of casualties. For instance, Prague in 1681 lost 83,000 due to plague. Dresden was affected in 1680, Magdeburg and Halle in 1682. In Halle, a mortality of 4397 out of a population of about 10,000 was recorded. Many north German cities suffered during these years; but, by 1683, the plague disappeared from Germany until the epidemic of 1707.

\subsection{The Great Plague of Florence, 1348}

The Black Death, otherwise known as bubonic plague or the pestilence, was the worst plague ever recording, killing 15 million people between 1347 and 1350 [3]. In fact, it was the second cycle of plague, however, that left its greatest imprint on the known world.

Around 1300 it began a rampage in Asia that then swept westwards, cutting huge swathes in populations from the Middle East to North Africa and Europe. Between 1347 and 1350 Europe alone is said to have lost some 20 million people to the disease. This pandemic, however, was just the first wave of a pestilence that continued to erupt until about 1800, when the second plague cycle mercifully came to an end.

Giovanni Boccaccio (1313-1375), Italian romantic poet and father of Italian fictional prose, in the early 1350's was employed by the Florentine government to serve as an ambassador. During this period he completed his most famous work, the Decameron (circa 1348-1353), a collection of 100 short stories or novel that were told during a ten-day period by ten Florentine escaping the plague (the Greek title means "for ten days") [4] (Figure 2).

It ravaged the city of Florencein 1348. The experience inspired him to write the Decameron, a story of seven men and three women who escape the disease by fleeing to a villa outside the city. In his introduction to the fictional portion of his book, Baccaccio gives a graphic description of the effects of the epidemic on his city. The Decameron, subtitled Prince Galehaut, is a collection of novels by the 14th century Italian author Giovanni Boccaccio. (Date written: 1351)

The Sign of Impeding Death "The symptoms were not the same as in the east, where a gush of blood from the nose was the plain sign of inevitable death; but it began both in men and women with certain swellings in the groin or un- 


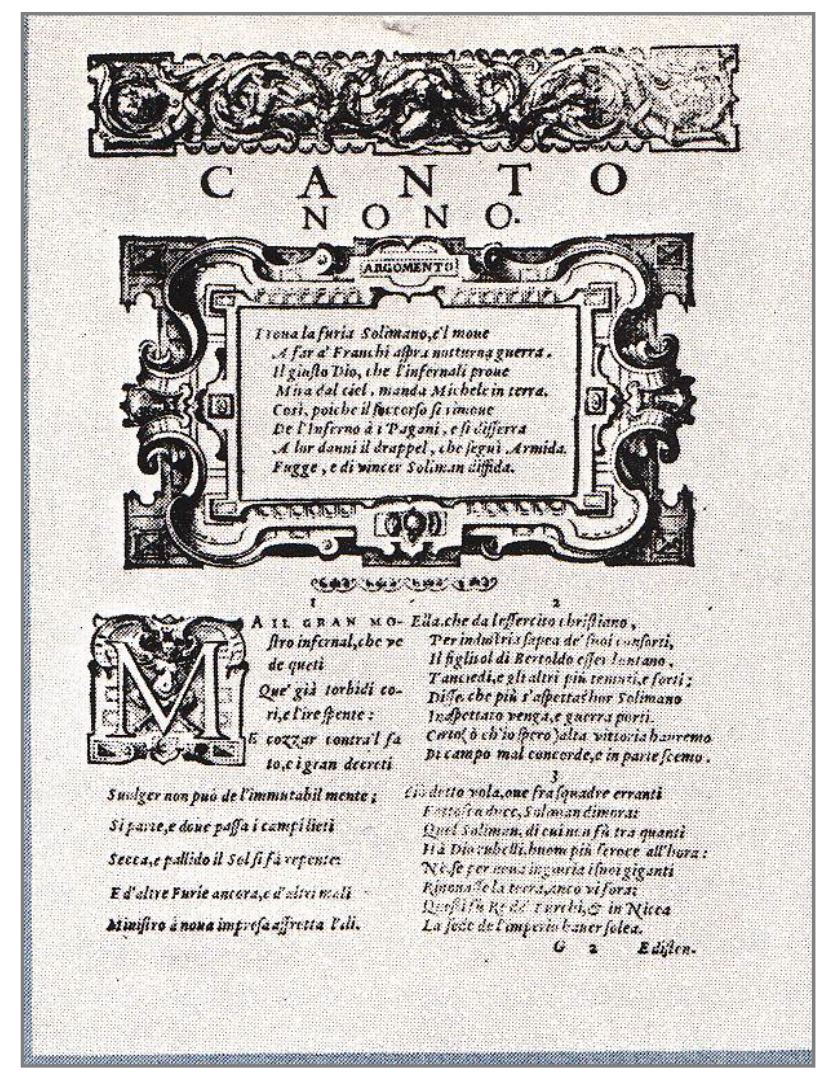

Figure 2. An illustration from Boccaccio's work, The Decameron, written about 1348-1353.

der the armpit. They grew to the size of a small apple or on egg, more or less, and were vulgarly called tumors. In a short space of time these tumors spread from the two parts named all over the body. Soon after this the symptoms changed and black or purple spots appeared on the arms or thighs or any other part of the body, sometimes a few large ones, sometimes many little ones. These spots were a certain sign of death, just as the original tumor had been and still remained.

No doctor's advice, no medicine could overcome or alleviate this disease. An enormous number of ignorant men and women set up as doctors in addition to those who were trained. Either the disease was such that no treatment was possible or the doctors were so ignorant that they did not know what caused it, and consequently could not administer the proper remedy. In any case very few recovered; most people died within about three days of the appearance of the tumors described above, most of them without any fever or other symptoms.

The violence of this disease was such that the sick communicated it to the healthy that came near them, just as a fire catches anything dry or oily near it. And it even went further. To speak to or go near the sick brought infection and a common death to the living; and moreover, to touch the clothes or anything else the sick had touched or worn gave the disease to the person touching."

Varying reaction to disaster: "...such fear and fanciful notions took posses- 
sion of the living that almost all of them adopted the same cruel policy, which was entirely to avoid the sick and everything belonging to them. By so doing, each one thought he would secure his own safety. Some thought that moderate living and the avoidance of all superfluity would preserve them from the epidemic. They formed small communities, living entirely separate from everybody else. They shut themselves up in houses where there were no sick, eating the finest food and drinking the best wine very temperately, avoiding all excess, allowing no news or discussion of death and sickness, and passing the time in music and suchlike pleasures. Others thought just the opposite. They thought the sure cure for the plague was to drink and be merry, to go about singing and amusing themselves, satisfying every appetite they could, laughing and jesting at what happened. They put their words into practice, spent day and night going from tavern to tavern, drinking immoderately, or went into other people's houses, doing only those thing which pleased them. This they could easily do because everyone felt doomed and had abandoned his property, so that most houses became common property and any stranger who went in made use of them as if he had owned them. And with all this bestial behavior, they avoided the sick as much as possible.

In this suffering and misery of our city the authority of human and divine laws almost disappeared, for, like other men, the ministers, and the executors of the laws were all dead or sick or shut up with their families, so that noduties were carried. Every man was therefore able to do as he pleased.

Many others adopted a course of life midway between the two just described. They did not restrict their victuals so much as the formernor allow themselves to be drunken and dissolute like the latter. But satisfied their appetites moderately. They did not shut themselves up, but went about, carrying flowers or scented herbs or perfumes in their hands, in the belief that it was an excellent thing to comfort the brain with such odors, for the whole air was infected with the smell of dead bodies, of sick persons and medicines.

Others again held a still more cruel opinion, which they thought would keep them safe. They said that the only medicine against the plague-stricken was to go right away from them. Men and women, convinced of this and caring about nothing but themselves, abandoned their own city, their own houses, their dwellings, their relatives, their property and went abroad or at least to the country round Florence, as if God's wrath in punishing men's wickedness with this plague would not follow them but strike only those who remained within the walls of the city, or as if they thought nobody in the city would remain alive and that its last hour had come."

The breakdown of social order "Brother abandoned brother": One citizen avoided another, hardly any neighbor troubled about others. Relatives never or hardly ever visited each other. Moreover, such terror was struck into the hearts of men and women by this calamity, that brother abandoned brother, and the uncle his nephew, and the sister her brother, and very often the wife her husband. What is even worse and nearly incredible is that fathers and mothers re- 
fused to see and tend their children, as if they had not been theirs.

Thus, a multitude of sick men and women were left without any care, except from the charity of friends (but these were few), or the greed, of servants, though not many of these could be had even for high wages, moreover, most of them were coarse-minded man and women, who did little more than bring sick what they asked for a watch over them when they were dying. And very often these servants lost their lives and their earnings. Since the sick were thus abandoned by neighbors, relatives and friends, while servants were scarce, a habit sprang up which had never been heard of before. Beautiful and noble women, when they fell sick, did not scruple to take a young or old man-servant, whoever he might be, and with no sort of shame, expose every part of their bodies to these men as if they had been women, for they were compelled by the necessity of their sickness to do so. This, perhaps, was a cause of looser morals on those women who survived."

\subsection{Mass Burials}

"The plight of the lower and most of the middle classes was even more pitiful to behold. Most of them remained in their houses, either through poverty or in hopes of safety, and fell sick by thousands. Since they received no care and attention, almost all of them died. Many ended their lives in the streets both at night and during the day; and many others who died in their houses were only known to be dead because the neighbors smelled their decaying bodies. Dead bodies filled every corner. Most of them were treated in the same manner by the survivors, who were more concerned to get rid of their rotting bodies than moved by charity towards the dead. With the aid of porters, if they could get them, they carried the bodies out of the houses and laid them at the door; where every morning quantities of the dead might be seen. They then were laid on biers or, as these were often lacking, on tables.

Such was the multitude of corpses brought to the churches every day and almost every hour that there was not enough consecrated ground to give them burial, especially since they wanted to bury each person in the family grave, according to the old custom. Although the cemeteries were full they were forced to dig huge trenches, where they buried the bodies by hundreds. Here they stowed them away like bales in the hold of a ship and covered them with a little earth, until the whole trench was full [5]."

\subsection{The Great Plague of London, 1665}

A dreadful plague (the Great Plague) of 1665 swept 100,000 soul away. Many merchants and traders and shopkeepers fled, taking up residence beyond the city $^{1}$. Some later become the first commuters, but many remained outside the

${ }^{1}$ London, political, economic, and cultural capital of the United Kingdom. London is really three cities: at the core is the tiny, 1-sq.-mi.-business center of the ancient traditional City of London; radiating from this is the 117 sq.-mi. governed by the London County Council; and finally Greater London, whose frontiers reach far out into the surrounding counties. 
city walls to develop the area around the West End. "A dreadful plague in London was in the year sixty five, which swept a hundred thousand souls away; yet I alive! [6]"; so wrote Daniel Defoe (circa 1660-1731), English journalist, pamphleteer, and novelist in "A Journal of Plague Year [7]" (1722) which is fiction but so realistic that it reads like reporting. I went all the first part of the time freely about the streets, though not so freely as to run myself into apparent danger, except when they dug the great pit in the churchyard of our parish of Aldgate. A terrible pit it was, and I could not resist my curiosity to go and see it. As near as I may judge, it was about forty feet in length, and about fifteen or sixteen feet broad, and, at the time I first looked at it about nine feet deep; but it was said they dug it near twenty feet deep afterwards in one part of it, till they could go no deeper for the water; for they had, it seems, dug several large pits before this...

Into these pits they had put perhaps fifty or sixty bodies each; then they made larger holes, wherein they buried all that the cart brought in a week, which, by the middle to the end of August, came to from 200 to 400 a week; and they could not well dig them larger, because of the order of the magistrates confining them to leave no bodies within six feet of the surface; and the water coming on at about seventeen or eighteen feet, they could not well, I say, put more in one pit. But now, at the beginning of September, the plagueragingin a dreadful manner, and the number of burials in our parish increasing to more than was ever buried in any parish about London of no larger extent, they ordered this dreadful gulf to be dug, for such it was rather than a pit.

They had supposed this pit would have supplied them for a month or more when they dug it, and some blamed the churchwardens for suffering such a frightful thing, telling them they were making preparations to bury the whole parish, and the like; but time made it appear the churchwardens knew the condition of the parish better than they did, for the pit being finished the 4 th of September, I think, they began to bury in it the 6th, and by the 20th, which was just two weeks, they had thrown into it 1114 bodies, when they were obliged to fill it up, the bodies being then come to lie within six feet of the surface. I doubt not but there may be some ancient persons alive in the parish that can justify the fact of this, and are able to show even in what place of the churchyard the pit lay better than I can. The mark of it also was many years to be seen in the churchyard on the surface. It was about the 10th of September that my curiosity led, or rather drove, me to go and see this pit again, when there had been near 400 people buried in it, and I was not content to see it in the day-time, as I had done before, for then there would have been nothing to have been seen but the loose earth; for all the bodies that were thrown in were immediately covered with earth by those they called the buriers, which at other times were called bearers; but I resolved to go in the night and see some of them thrown in.

There was a strict order to prevent people coming to those pits, and that was only to prevent infection. But after some time that order was more necessary, for people that were infected and near their end, and delirious also, would run to 
those pits, wrapped in blankets or rugs, and throw themselves in, and, as they said, bury themselves. I cannot say that the officers suffered any willingly to lie there; but I have heard that in a great pit in Finsbury, in the parish of Cripplegate, it lying open then to the fields, for it was not then walled about, some came and threw themselves in, and expired there, before they threw any earth upon them; and that when they came to bury others, and found them there, they were quite dead, though not cold.

This may serve a little to describe the dreadful condition of that day, though it is impossible to say anything that is able to give a true idea of it to those who did not see it, other than this, that it was indeed very, very, very dreadful, and such as no tongue can express. I got admittance into the churchyard by being acquainted with the sexton who attended, who though he did not refuse me at all, yet earnestly persuaded me not to go, telling me... that I had no apparent call to it but my own curiosity, which, he said, he believed I would not pretend was sufficient to justify my running that hazard...

I stood wavering for a good while, but just at that interval I heard the bellman, and then appeared a dead-cart, as they called it, coming over the streets; so I could no longer resist my desire of seeing it, and went in. There was nobody, as I could perceive at first, in the churchyard, or going into it, but the buriers and the fellow that drove the cart, or rather led the horse and cart; but when they came up to the pit they saw a man go to and again, muffled up in a brown cloak, and making motions with his hands under his cloak, as if he was in a great agony, and the buriers immediately gathered about him, supposing he was one of those poor delirious or desperate creatures that used to pretend, as I have said, to bury themselves...

When the buriers came up to him they soon found he was neither a person infected and desperate, as I have observed above, or a person distempered in mind, but one oppressed with a dreadful weight of grief indeed, having his wife and several of his children all in the cart that was just come in with him, and he followed in an agony and excess of sorrow...

This was a mournful scene indeed, and affected me almost as much as the rest; but the other was awful and full of terror. The cart had in it sixteen or seventeen bodies; some were wrapped up in linen sheets, some in rags. Neither was it possible there should be, for coffins were not to be had for so many.

Some little other than naked, or so loose that what covering they had fell from them in the shooting out of the cart, and they fell quite naked among the rest; but the matter was not much to them, or the indecency much to any one else, seeing they were all dead, and were to be huddled together into the common grave of mankind, as we may call it, for here was no difference made, but poor and rich went together; there was no other way of burials, neither was it possible there should be, for coffins were not to be had for so many [8].

\subsubsection{Samuel Pepys and the Great Plague of London}

Samuel Pepys PRS (1633-1703) an English naval administrator and member of 
parliament who is now famous for a diary who kept for a decade while still a relatively young man. As a true Londoner when Pepys faced the great plague he refused to leave the city and when Samuel saw London destroyed by the great fire hewept.

He reports: The peak of the epidemic was the week of 19-26 September 1665 when London mortality bills recorded 7165 deaths from plague. London now appeared almost deserted during the day. Grass grew on the streets of Whitehall and the court fled London for Oxford. In the city, the keeping of dogs, cats, and other domestic animals was banned and the dog-catcher destroyed over 4,000 dogs. Boats no longer sailed on the Thames and the Navy wisely kept its ships away from London.

Night after night, porters took piles of corpses for burial, filling large pits with the dead. Adding to the horror were rumors of the bereaved and the ill throwing themselves into the pits alive. "I having stayed in the city till above 7400 died in one week and of them above 6000 of the plague, and little noise heard day or night but tolling of bells; till 1 could walk Lombard Street, and not meet twenty persons from one end to the other ... till whole families (ten and twelve together) have been swept away ... till the nights (though much lengthened) are grown too short to conceal the burials of those that died the day before." (Figure 3).

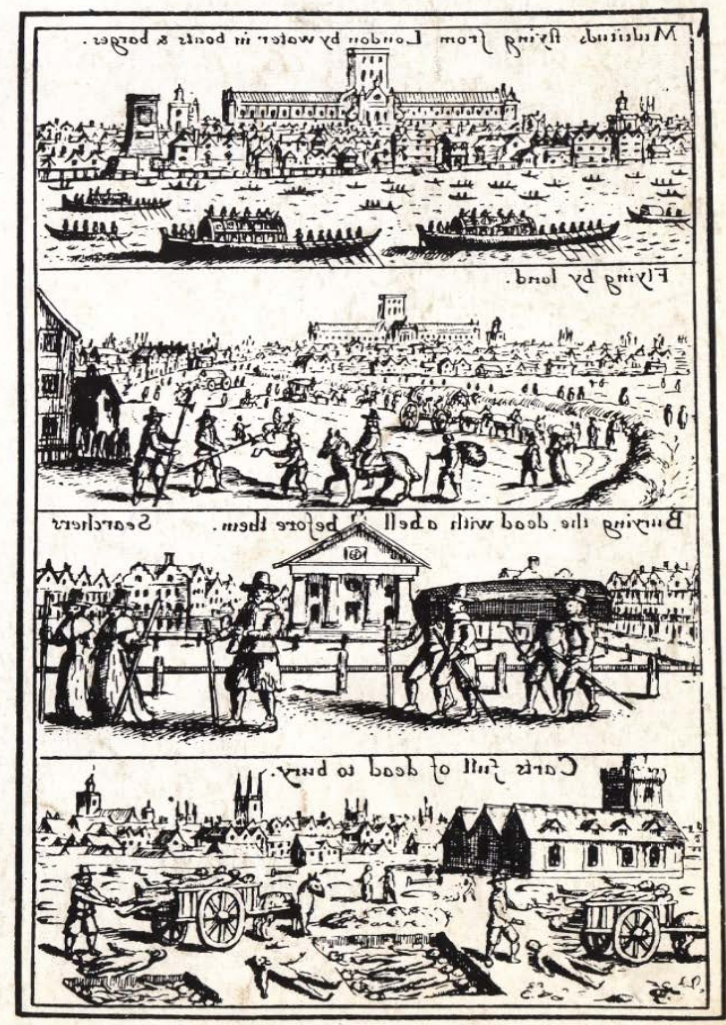

Figure 3. Four of many posters made to illustrate The London Plague in 1665-1666. In the bottom, it shows the long trenches dug to bury the dead and the heavily loaded carts bringing bodies to burial. 


\subsubsection{Samuel Pepys' Letter to Elizabeth Lady Carteret, 4 September 1665}

Plague deaths rose rapidly in the spring of 1665; by June a quarter of deaths recorded in London were attributed to the plague, by August this figure had risen to 75 percent.

By early 1666 the number of people dying from the plague was receding and the epidemic was all but over by the Summer of 1666 . The last reported case of the plague in London was in 1679. Although no one knew it at the time, this would mark the end of the era of plague that had devastated populations across Europe from the 14th century.

Some looked to the alignment of the planets or the ominous appearance of a comet in December 1664 to explain the epidemic.

Medical folk discussed the transmission of the illness through bad smells. There was a good trade in nosegays and pomanders stuffed with medicinal herbs, and a proposal to float a ship of peeled onions down the Thames to counter the evil odors was entertained. Some people put their faith in amulets and charms or, like Samuel Pepys, chewed tobacco to ward off the plague: "I was forced to buy some roll tobacco to smell to and chaw-which took away the apprehension." (Samuel Pepys, 7 June 1665-.) (Figure 4).

The plague was actually caused by infected fleas carried by black rats, although this would not be known for centuries to come. Rats were particularly prevalent in the cramped and dirty streets of the capital occupied by the poorest residents.

\subsubsection{The Great Plague in Number}

Official number of deaths: 68,595 victims.

Likely number of deaths: 100,000 victims.

Most deaths in a week: 7615 victims.

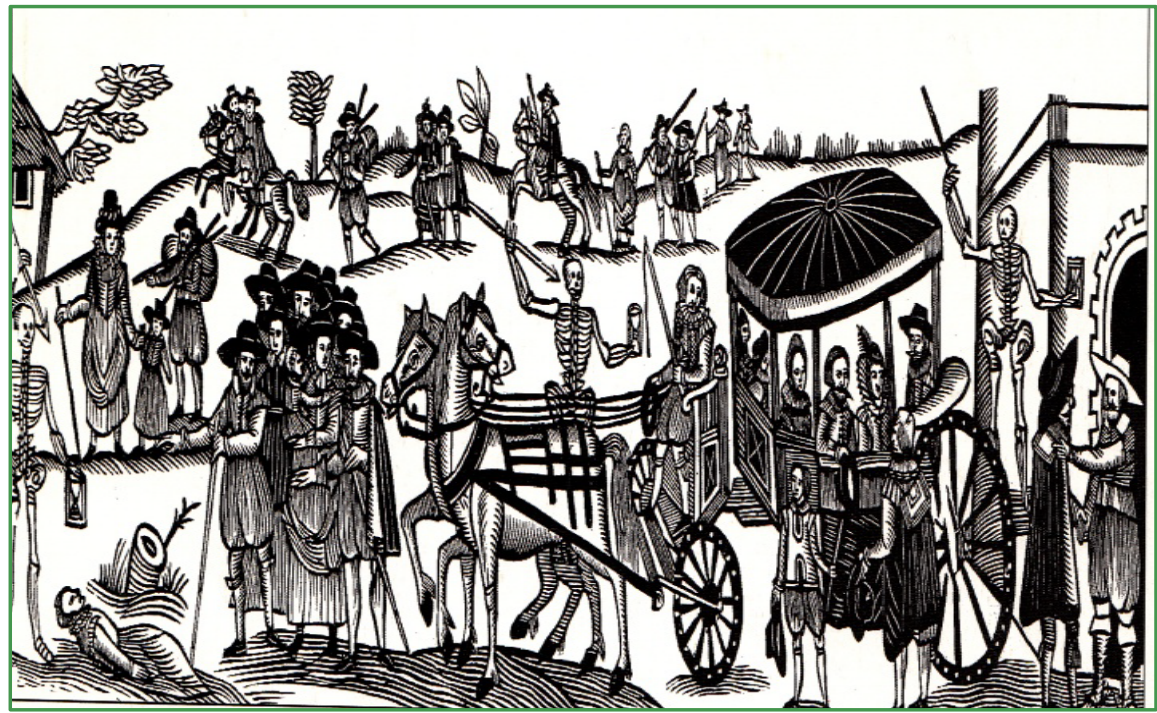

Figure 4. Londoners fleeing from the Great Plague of 1965, when a large proportion of the citizens of London died. 
In total the Great Plague of London wept out nearly a quarter of the population of the city.

\subsubsection{The Plague through Samuel Pepys's Eyes}

October 1663: First mention of the plague in Pepys's diary. "The plague is much in Amsterdam, and we in fears of it here-which god defend."

February 1664: First death from plague "recorded by London mortality bills in the parish of St Giles-in-the-Fields."

May 1665: Six more London parishes infected. "all the newes \{news\}... of the plague growing upon us in this town; and of remedies against it: some saying one thing some another."

June 1665: First mentions of houses shut up. ... a red cross upon the doors, and "Lord have mercy upon us"... (25 percent of all London deaths caused by the plague).

July 1665: A four-fold increase of deaths with over 4000 recorded in the mortality bills for the month (75 percent of all London).

August 1665: Pepys's physician dies. "This day I am told that Dr. Burnett, my physician, is this morning dead of the plague..."

September 1665: 26,000 people in London die (of all London deaths caused by plague).

October 1665: The colder weather helped to recede the deaths but almost 15,000 people died in this month.

\subsubsection{Official Deaths in 1665: 68,595 Victims}

January 1666: Life begins to return to normal, although deaths from the plague remain in their hundreds.

\subsubsection{The Disappearance of Bubonic Plague from England}

The Black Death has, furthermore, appeared at various time and different places in the pneumonic and septicemic (blood-poisoning) forms, spreading through airborne particles from person to persona pathway evoked in the children's nursery rhyme:

Ring-a-ring o' roses, A pocket full of posies, Atishoo, atishoo We all fall down.

One of the greatest puzzles of our epidemiological past remains the reason for the disappearance of bubonic plague from Britain after 1665-1666 (with the exception of one brief outbreak in twentieth-century Suffolk). Traditional ideas, such as the displacing of the black rat by the less friendly brown rat (Rattusnorvegicus) or the cleansing of the urban environment by the great fire of London ${ }^{2}$, have long been dismissed by historians as inadequate explanations. A plethora of ${ }^{2}$ Conflagration in 1666 that destroyed most of city proper, an area which dated from medieval times. Coming soon after the great plague and the midst of the second Dutch war, it seemed to many, the manifestation of God's displeasure and a harbinger of still other disasters. (Encyclopedia International. Vol. 11, P. 72.) From the embers of the Great London fire came the world's first organized fire department since the the time of the Romans. (Ibid. Vol. 7, P. 134.) Modern fire insurance also began with the great fire of London. (Ibid. Vol. 9, P. 321.) 
alternative hypotheses have been presented in the literature but the sudden shift in Britain's epidemiological cycle of events still retains its place as the mystery of history [9].

\subsection{The Great Plague of Milan, 1629}

The Italian plague of 1629-1631 was a series of outbreaks of bubonic plague which ravaged northern and central Italy. The great plague of Milan (this epidemic often referred as the Great Plague) killed over half of its population: 80,000 in Milan and 500,000 in Venice. This episode is considered one of the later outbreak of the centuries-long pandemic of bubonic plague which began with the Black Death (Figure 5).

German and French troops carried the plague to the city of Mantua in northern Italy (capital of Mantoua province, Lombardy region) in 1629, as a result of troops movement associated with the Thirty Years' War (1618-1648). Venetian troops, infected with the disease, retreated into northern and central Italy, spreading the infection. In October 1629, the plague reached Milan, Lombardy's major commercial center. Although the city initiated effective public health measures, including quarantine and limiting the access of German soldiers and trade goods, the plague smoldered. A major outbreak in March 1630 was due to relaxed health measures during the carnival season. This was followed by a second wave in the spring and summer of 1631. Overall, Milan suffered approximately 60,000 fatalities out of a total population of 130,000 .

East of Lombardy, the republic of Venice was infected in 1630-1631. The city of Venice was severely hit, with recorded casualties of 46,000 people out of a population of 140,000. Some historians believe the drastic loss of life, and its impact on commerce, ultimately resulted in the downfall of Venice as a major commercial and political power. The papal city of Bologna lost an estimated

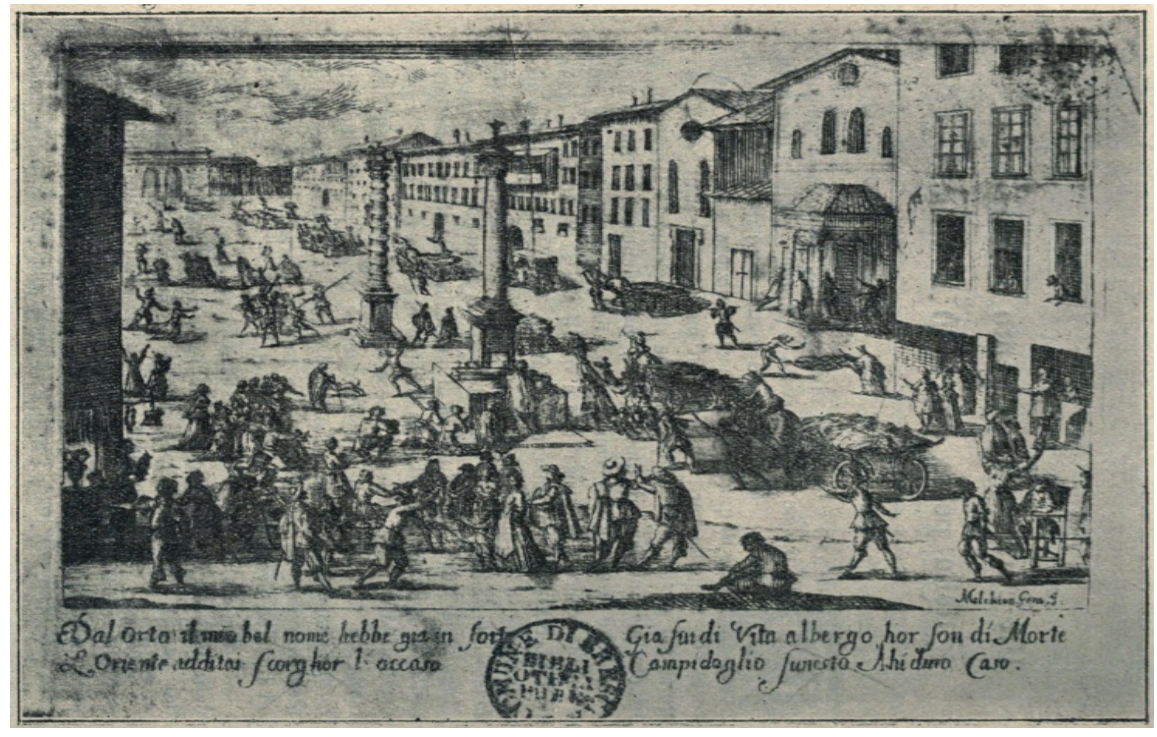

Figure 5. Plague carts carry the dead for burial (Milan: Plague of 1630). 
15,000 citizens to the plague, with neighboring smaller cities of Modena and Parma also being heavily affected. This outbreak of plague also spread north into Tyrol, an Alpine region of western Austria and northern Italy [10].

Later, outbreaks of bubonic plague in Italy include the city of Florence in 1630-1633 and the areas surrounding Naples, Rome and Genoa in 1656-1657.

The plague of 1630 in Milan is the backdrop of several chapters of the Betrothed (Italian: I promessisposi) ${ }^{3}$, famous written by Alessandro Manzoni (Francesco Tommaso Antonio, 1785-1873) Italian author. The chapters 31-33 are occupied with an account of the plague of 1630, largely based on GiusepeeRipamonti's De peste quae fuit anno 1630 (published in 1640). Manzoni's full version of this, "Storiadella Coloma infame" was finished in 1829, but was not published until it was included as an appendix to the revised edition of 1842 . The end of August 1630 sees the death in Milan of original villains of the story. Renzo, troubled by Agnese's letters and recovering from plague, returns to his native village to find that many of the inhabitants are dead and that his house and vineyard have been destroyed. ... Therothed although is a work of fiction, Manzoni's description of the conditions and eventsin plague ravaged Milan are completely historical and extensively documental from primary sources researched by the author [11].

\subsection{The Great Plague of Vienna, 1679}

It occurred in Vienna, Austria in 1679, the imperial residence of the Austrian Habsburg rulers. From contemporary descriptions, the disease is believed to have been bubonic plague, which is caused by the bacterium Yersinia pestis, carried by fleas associated with the black rat and other rodents. The city was crippled by the epidemic, which recurred fitfully into the early 1680 s, claiming an estimated 76,000 residents.

Vienna, on the Danube River, in north eastern part of Austria was a major trading crossroads between east and west. As a result of this traffic, the city had suffered from episodic plague outbreak since the first wave of "Black Death" in the fourteenth century. The city was crowded and densely built. Descriptions indicate that there were no public sewers or drainage systems, with stinking mounds of domestic garbage littering the streets. In addition, warehouses for trade goods, which held item such as clothing, carpets, and grain for months at a time, were heavily infested with rats. Conditions in the city were considered so unhealthy and filthy, even for the time, that the plague often carried the title "Viennese death" in other parts of Europe.

A religious order operating in Vienna, the Brotherhood of the Holy Trinity, created special hospitals for both children and adult during the 1679 epidemic. The basic nursing care offered in the hospitals was simple, but was generally a

${ }^{3}$ Setin Lombardy during the Spanish occupation of the late 1630s. The Betrothed tells the story of tow young lovers, Renzo and Lucia, prevented from marrying by the petty tyrant Don Rodrigo, who desires Lucia for himself. Forced to flee, they are then cruelly separated, and must face many dangers including plaque, famine and imprisonment, and confront a variety of range... 
vast improvement over other medical and public health measures in the city. Doctors treated patients by using emetics, bloodletting, and by applying noxious ointments. The corpses of plague victims were carted to the outer edges of the city and placed in large open pits for burning. However, the pits were exposed to the open air for several days until they were nearly full, allowing ongoing infection of the rat population.

The great plague of 1679 gave rise to the legend of Lieber Augustin ("Dear Augistin"). Augustin was a popular street musician, who, according to the legend, fell into a pit with bodies of plague victims, late at night when he was drunk. Augustin did not contract the disease, which may have been owed to the influence of the alcohol. Augustin is remembered in the popular folk song "Oh du Lieber Augustin.”

To commemorate the city's deliverance from the great plague and later waves of the disease, the Viennese erected monuments such as the famous Baroque Karlskirche with the associated 69 foot plague columns known as the Pestsäule [12].

\subsection{The Great Plague of Marseille, 1720-1721}

The plague of 1720-1721 wept out approximately half the population of Marseille, leading commercial seaport and second largestcity in France.This great outburst of plague was the last recurrence of a pandemic of bubonic plague, following the devastating episodes which began in the mid-fourteenth century with the European Black Death. In 1720, the plague bacillus Yersinia pestis arrived at the port of Marseille from the Levant. The merchant ship, the Grand-Saint-Antoine, had departed from Sidon in Lebanon, having previously called at Smyrna, Tripoli, and plague-ridden Cyprus. Following the death on board of a Turkish passenger, several crew members fell victim to the plague, including the ships surgeon. The ship was refused entry to Livorno and, on arrival at Marseille, was promptly placed under quarantine in the Lazaret by the port authorities. Due largely to its monopoly on French trade with the Levant, this important port had a large stock of imported goods in warehouses and actively expanding its trade with other areas of the Middle East and emerging markets in the New World. Powerful city merchants needed the silk and cotton cargo of the ship for the great medieval fair at Beaucaire and pressured authorities to lift the quarantine (Figure 6).

A few days later, the disease broke out in the city. Hospitals were quickly overwhelmed, and residents panicked, driving the sick from their homes and out of the city. Mass graves were dug but were quickly filled. Eventually the number of dead overcame city public health efforts, until thousands of corpses lay scattered and in piles around the city. Attempts to stop spread of plague included an Act of the parliament of Aix that levied the death penalty for any communication between Marseille and the rest of province. To enforce this separation, a plague wall, the "Mur de laPeste" was erected across the countryside. The wall 


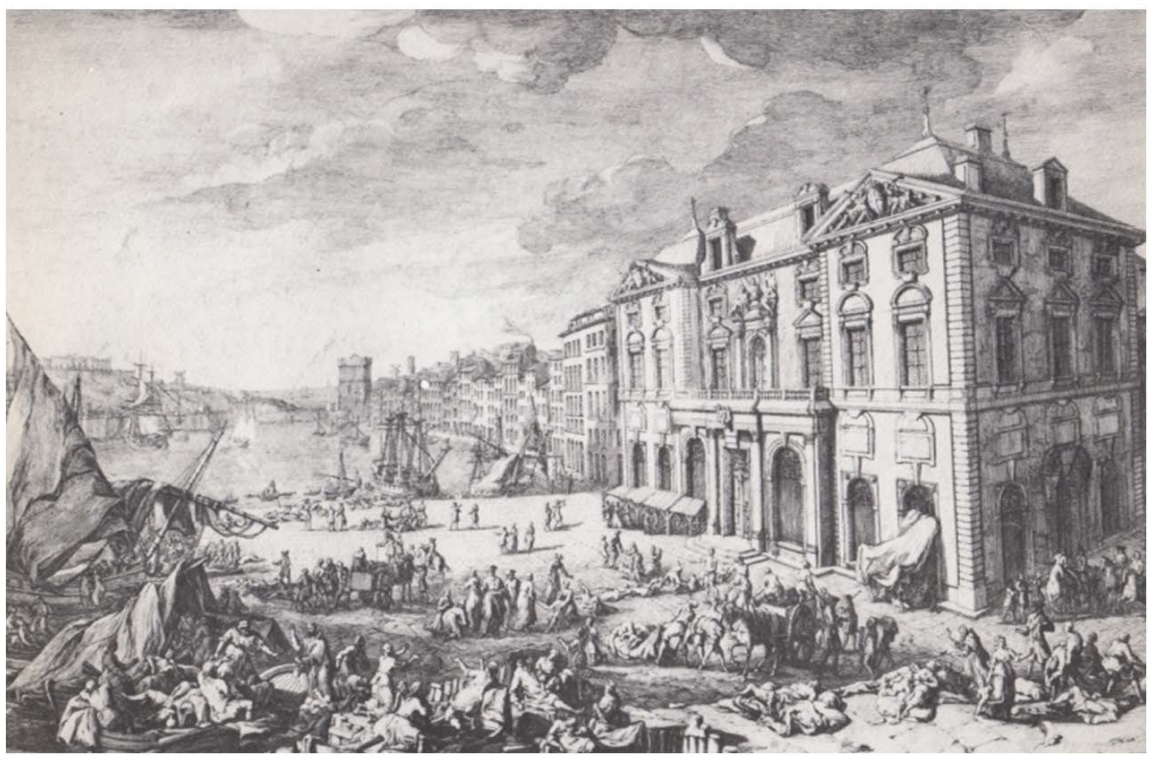

Figure 6. A painting made on the spot, showing the Marseilles town hall with citizens attempting to flee the plague of 1720 .

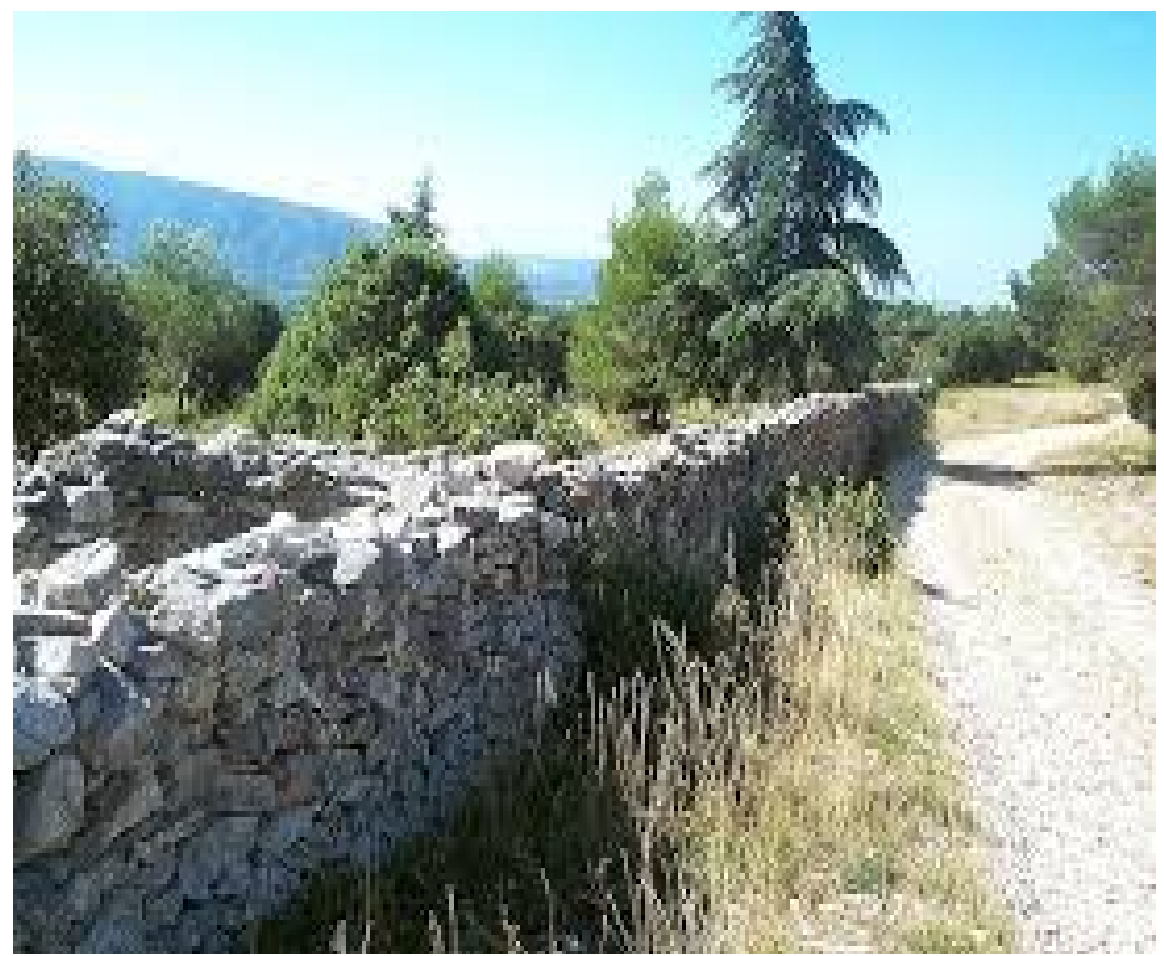

Figure 7. The "Mur de la peste" (The wall of the pest-house).

can still be seen in different parts of the Plateau de Vaucluse (Figure 7).

During a two-year period, 50,000 of Marseilles total population of 90,000 died, and an additional 50,000 people succumbed as the plague spread north, eventually reaching Aix-en-Provence, Arles, Apt and Toulon. Estimates indicate an overall death rate of between 25 percent - 50 percent for the population in the larger area, with the city of Marseille at 40 percent, the area of Toulon at above 
50 percent, and the area of Aix and Arles at 25 percent.

After the plague subsided, the royal government strengthened the plague defenses of the port, building the waterside Lazaret d'Arenc. A double line of fifteen-foot walls ringed the whitewashed compound, pierced on the waterside to permit the offloading of cargo from lighters, once merchantmen had passed inspection at an island further out in the harbor, where crews and cargoes were examined [13].

\subsection{The Moscow Plague Riot of 1771}

It was a riot in Moscow between 15 and 17 September 1771. Approximately 200,000 people died in Moscow and its outskirts during the outbreak of plague. The first signs of plague in Moscow appeared in late 1770, which would turn into a major epidemic in the spring of 1771 . The measures undertaken by the authorities, such as creation of forced quarantines, destruction of contaminated property without compensation or control, closing of public baths, etc., caused fear and anger among the citizens. The city's economy was mostly paralyzed because many factories, markets, stores, and administrative buildings had been closed down. All of this was followed by acute food shortages, causing deterioration of living conditions for the majority of the Muscovites. Dvoryane (Russian nobility) and well-off city dwellers left Moscow due to the plague outbreak.

The first outbursts of mass protest against the measures undertaken by the authorities took place on August 29 and September 1 in a neighborhood of Lefortovo. By early September, the rumors of an imminent uprising had already been circulating. An attempt by the Archbishop Ambrosius of Moscow to prevent the citizen from gathering at the Icon of the Virgin Mary of BogolyubovoinKitai-gorod as a quarantine measure served as an immediate cause for the Plague Riot. On September 15, huge crowds of Moscovites began to flow towards the Red Square and the sound of the alarm bell. Pushing aside a military unit, they burst into the Kremlin and destroyed the ChudovMonastery (archbishop's residence) and its wine cellars. Archbishop Ambrosius managed to escape to the Donskoy Monastery.

On September 16, the riot gained in strength. Angry citizens captured the DonskoyMonastery, killed Archbishop Ambrosius, and destroyed two quarantine zones (Danilov Monastery and the one beyond the Serpukhov Gates). In the afternoon, most of the rebels approached the Kremlin and were met by a number of military units. The crowd demanded the surrender of Lieutenant GeneralPyotrYeropkin, who had been overseeing the affairs of Moscow after PyotrSaltykov's departure. As soon as the Moscovites tried to attack the Kremlin's Spasskiye Gates, the army opened fire with buckshot, dispersing the crowd and capturing some of the rebels. On the morning of September 17, around 1000 people gathered at the SpasskiyeGates again, demanding the release of captured rebels and elimination of quarantines. The army managed to disperse the crowd yet again and finally suppressed the riot. Some 300 people were brought to trial. 
A government commission headed by GrigoryOrlov was sent to Moscow on September 26 to restore order. It took some measures against the plague and provided citizens with work and food, which would finally pacify the people of Moscow. The commission improved services in quarantines, put an end to the burning of property, reopened public baths, permitted trade, increased food deliveries, and organized public works. At the same time, the commission was engaged in prosecuting those who had taken part in the Plague Riot. Four of them were executed; 165 adults and twelve teenagers were subjected to punishment. With the onset of cold weather, the outbreak began to subside. Around 200,000 people died in Moscow and its outskirts during the plague (Figure 8).

There was another unlikely convict-the church bell that was used to start the alarm. By the order of Catherine II, an executor cut the tang from the bell. For

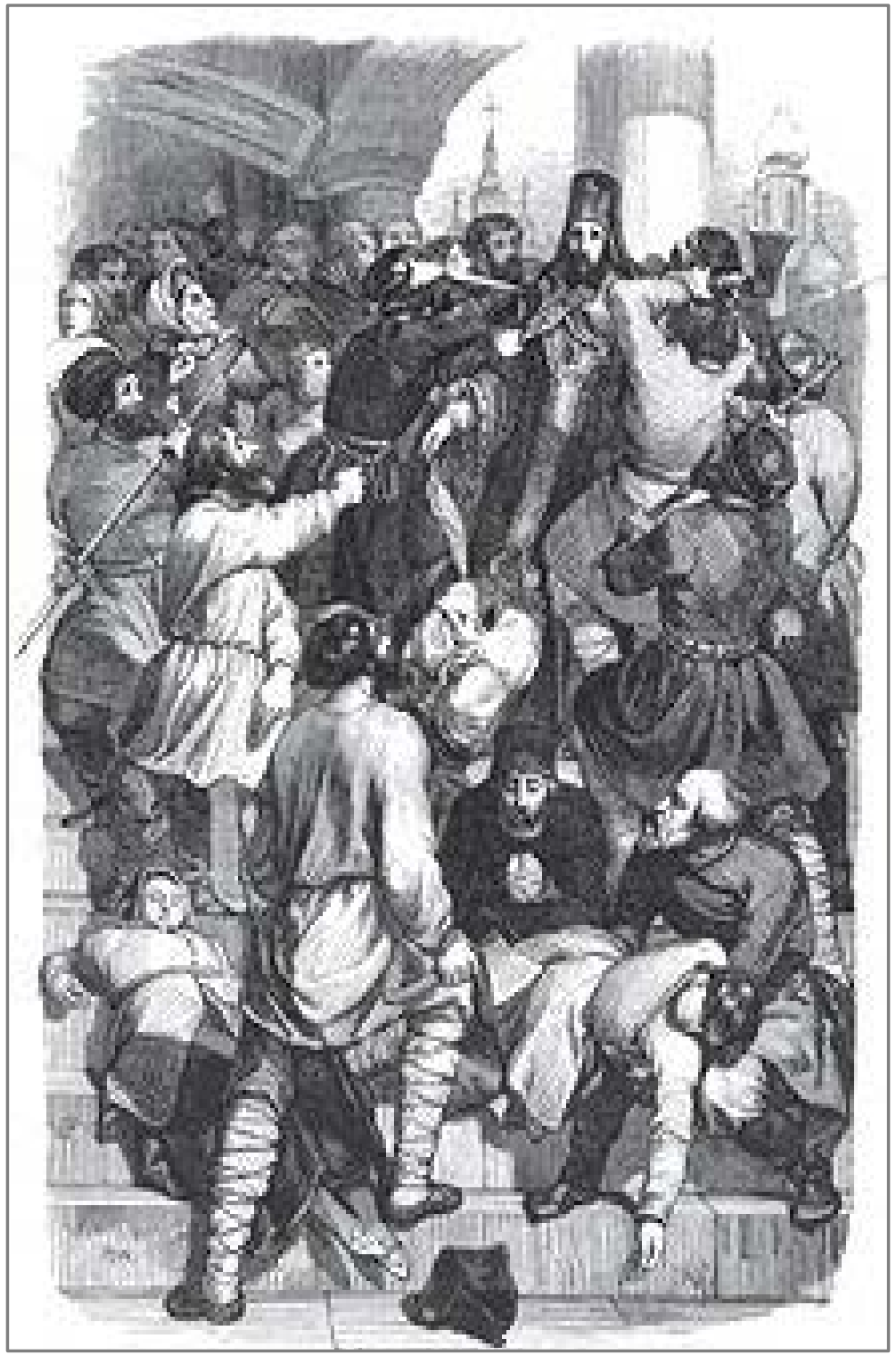

Figure 8. The murder of Archbishop Ambrosius. 
more than thirty years, the silent bell hung on the bell tower. Eventually, in 1803, it was removed and sent to the Arsenal and, in 1821, to the Kremlin Armoury [14].

\subsection{Plague Epidemic in Iran}

To Persian (Iranian) physicians, plague was known one the devastating diseases. Abu SahlMassihi (971-circo 1009) Persian Christian physician (contemporary of Avicenna) wrote "Maqalafita'un". HalyAbbas (born 930) famous Iranian physician whose principal work, Kamil al-Sina'aul-țbbiya (the complete medical art) was divided into two sections on theoretical and practical medicine, gave accurate description of plague. Furthermore, Avicenna (980-1037) Iranian philosopher and great physician, called the prince of physician who wrote an enormous and influential "Canon of Medicine" described the bubonic plague. Another Iranian famous physician, SeyyedIsma'ilJurjani (1042-circa 1137) described the symptom of bubonic plague (swelling in the armpits and groin).

During the Safawid period (1503-1736), several outbreak of plague were occurred, in Qazvin and Ardabil 30,000 people died. In Qum, a city in the sought of Tehran, during five years 12,000 were died of plague.

During the reign of Shah Abbas the Greet (1587-1629), the cholera and plagueoccurred concurrently. In Shah Safi'sreign (1629-1642), asevere outbreak of plague occurred in Qazvin, a city in the west of Tehran and spread to other cities including Abhar, Taroum, Khalkhal, Zanjan, and Azarbaijan and Gilanprovences. In the epidemic of Qazvin 20,000 were died from plague. In 1727, during the Afgans invasion (after the collapse of Safawid Dynasty), plague devastated Gilan and four years later in Hamedan (in the western part of Iran), the plague victims reached around 20,000.

During the reign of Qajars, in Saqez and Baneh (two cities of Kurdistan province, in the west of Iran) an outbreak ofplague occurred and several Iranian and foreign physicians (working in Iran) were assigned to control thedisease. Dr. Johan Louis Schlimmer (1819-1881), the eminent Dutch professor of modern medicine at Dar al-funūn (Medical School) was one of the them who noted his observations regarding plague outbreak of Kurdestan as part of his medical work (in Persia), entitled "Terminologie medico-pharmaceutique et anthropologiquefrançaise-persane" (1874).

In 20th century, another epidemics of plague began in Kurdistan and in Khurasan, Torbatijam (1913) and one outbreak in 1921.

Modern Medical Books on Plague: Perhaps the first Iranian physician who wrote on plague was MuhammadAazi Țabațabaeithe chief of military physicians during the reign of Nasser al-Din Shah entitledTa'uon (the plague), was published in 1876 included five chapters and an addendum contained the writings of Joseph DesiréTholozan (1820-1897) on the prevention and treatment of plague (Figure 9). Dr. Tholozan, Nasser al-DinShah's private physicianand the first chief of the Sanitary Council (MajlisHifsal-sihha) of Iran, which was founded 


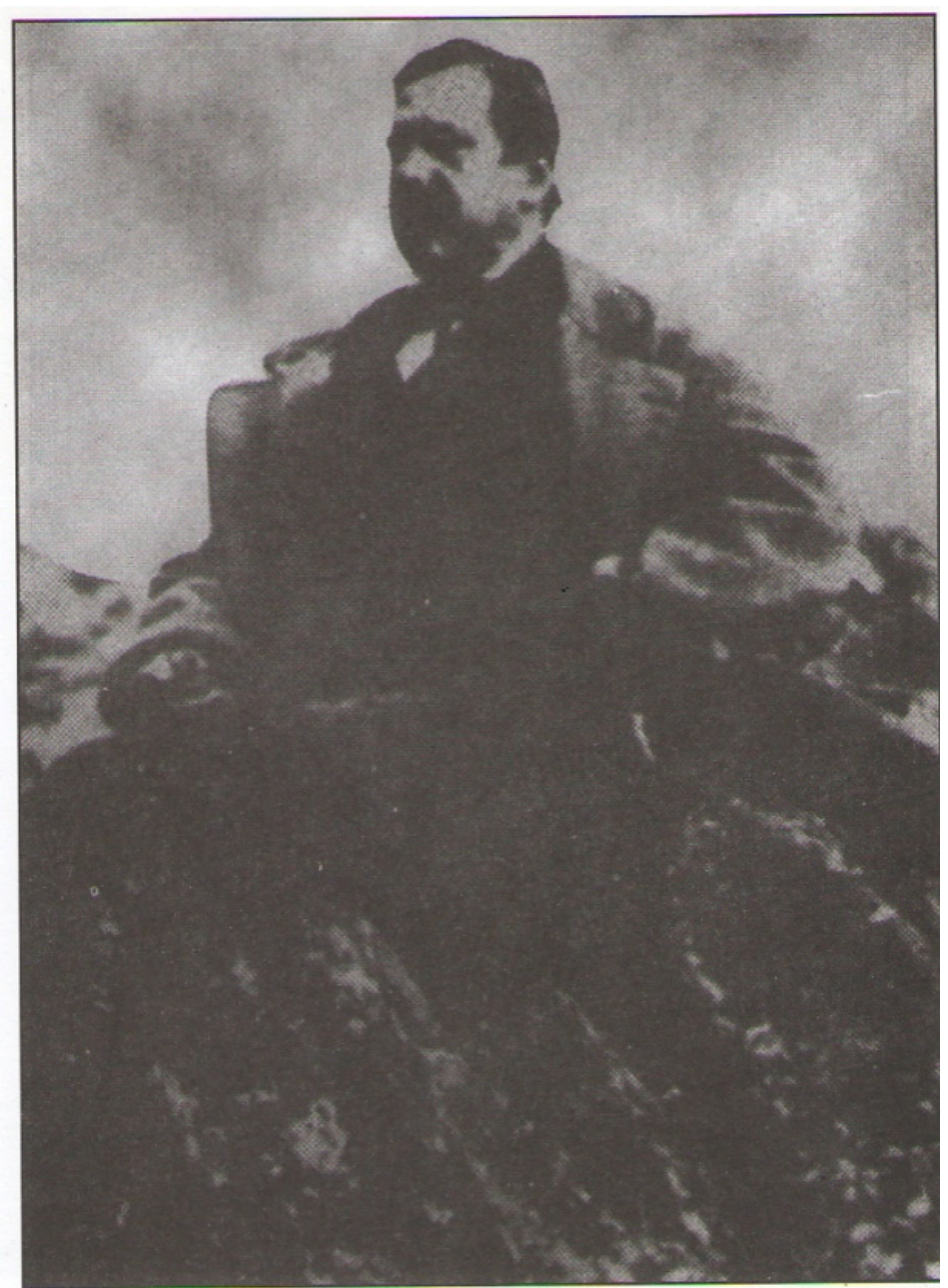

Figure 9. Dr. Tholozan the Shah of Iran's private physician who studied and described the foci of plague in several villages in Kurdistan.

during Nasser al-Din Shah's Era. He made a scientific investigation on the human plague in Kurdestan and Khurasan provinces and published the results of his study between 1870 and 1882 . Tholozan studied the natural plague foci in Kurdestanprovince in western Iran and precisely described the foci of the disease in some villages of Kurdestanprovince. His writing on the history of plague in Iran was published in Tehran in 1876.

\subsubsection{Major Outbreaks of Plague in Iran}

Major outbreaks of plague in Iran during 19th and 20th centuries (the Qajars period) in Iran:

1829-1833: in Caspian Sea littoralnumber of death unknown.

1829-1833: in Khurasan province; number of deaths unknown.

1871: in Kurdistan province; number of deaths unknown. The Italian physiciansCastaldi and Cabuzzi, in 1871, came from Istanbul for the help.

1877: in Caspian Sea littoral; number of deaths unknown.

1877: inKhurasan; number of deaths unknown. 
1877: Shushtar (in Khuzistan) 1800 victims of plague.

1899: Persian Gulf region; number of deaths unknown.

1906: Sistan; 1409 deaths. Downward effect on trade, migration of the residents due to the poor economy.

1910: Bushihr; 66 deaths.

1911: Bushihr; 98 deaths. The most important epidemic in Sistan in the south east of Iran, the plague interedfrom India, probably due to old clothing imported by Indian merchants.

1912: Bushihr; 725 deaths, 4000 were vaccinated, of 965 cases, 725 patientsor 75 percent died.

1913: Torbatijam in Khurasan and Kurdistan; number of deaths unknown. (Karimi. P. 15)

1917: Khuramshahr (former Mohammarah), in Khusistan, number of deaths unknown. In this city, of 79 patients, 43 died, and in Abadan, of 481 patients, 409 died.

1921: Torbatijam and Kariz in Khurasan; number of deaths unknown.

1923: Khuramshahr in Khuzistan; 43 victims of plague.

1923: Abadan in khuzistan; 409 victims.

1924: Khuramshahr, Abadan, and Bushihr and Bandar Abbas; number of deaths unknown.

Quarantine Station: Due to the increase in international trade, transoceanic shipping and episodes of fatal epidemics, quarantine was considered as a significant tool for epidemic prevention. After a plague outbreak in 1877, the idea to establish quarantine stations in Iran was recommended, but their foundation was delayed until 1899, after a severe plague outbreak in the Persian Gulf region. In 1899, a quarantine station was founded in the port of Bushehr. Then, in 1905, a conference was held in Paris on quarantine and it was suggested to the Iranian officials to establish quarantine stations in Bandar Abbas, Bushihr, Bandar Lengeh, Abadan, and Bandar Jask. Thus a quarantine station in Bushehr was founded and managed by English staff until 1928, and in due course, Iranian personnel supervised it. In 1927, the Public Health Administration Office wrote a letter to the Ministry of Interior to allocate a budget for the establishment or reconstruction of quarantine stations in Julfa, Ghasr Shirin, Bandar Anzali, and Astara. The total requested money was 145,000 tomans (Iranian currency) which was allocated by the Ministry of Interior. Although the quarantine stations of Bandar Anzali and Astara were built in 1912, the Astara Quarantine station was destroyed during the First World War. In 1923, some preventive measures to control the plague epidemic in Abadan, Khuzestan province were applied. A total of 4,534 people were vaccinated against the plague, patients were quarantined and death certificates became mandatory for better detection of the plague victims.

Pasteur Institute: The Pasteur Institute of Iran was founded in 1921 and it was connected scientifically to the Paris Institute of Pasteur. In 1946, Dr. Marcel Baltazard (1908-1971) was appointed as the director. He remained in Tehran as 
the director until 1961. Dr. Baltazard was a great researcher, particularly in the field of epidemic diseases including the human plague.

Plague in Kurdistan: In 1947, in Kurdestanprovince, an outbreak of pneumonic plague occurred in the villages of Sameleh and Aghbolagh-e Morshed. The Iranian research team of the Pasteur Institute of Iran supervised by Dr. Baltazard went to Kurdestan to begin scientific investigation into this plague outbreak. The research team of the Pasteur Institute established a research plague center in a village called Akinlo, Hamadan province (100 km from Hamadan and approximately $200 \mathrm{~km}$ from Aghbolagh-e Morshed village). The activities of the Akinlo Research Plague Center continued for about 20 years. Dr. Baltazard and his Iranian colleagues, including Dr. Mansour Shamsa and Dr. YounesKarimi, eventually found the plague bacilli infected reservoirs among the rodents in Kurdistan province as well as the natural plague foci in the region. They published several scientific papers on the human plague in Iran. In an article published in 1960, Baltazard and his Iranian colleagues (M. Bahmanyar, P. Mostachfi, M. Eftakhari, and Ch. Mofidi) pointed out that this co-operative efforts led to the identification of four species of rodents, of which two (Merioneslibycus and Merionespersicus) were highly resistant to plague and the other two (Merionestristrami and Merionesvinograbovi) were extremely susceptible.

At that time, an active and prominent researcher of the human plague was Dr. YounesKarimi (1929-2009; born in Darreh-Gaz, Khurasanprovince) who graduated from the Tehran School of Medicine and became a specialist of infectious diseases. Dr. Karimi later continued his studies in microbiology and immunology at the Pasteur Institute of Paris (Figure 10).
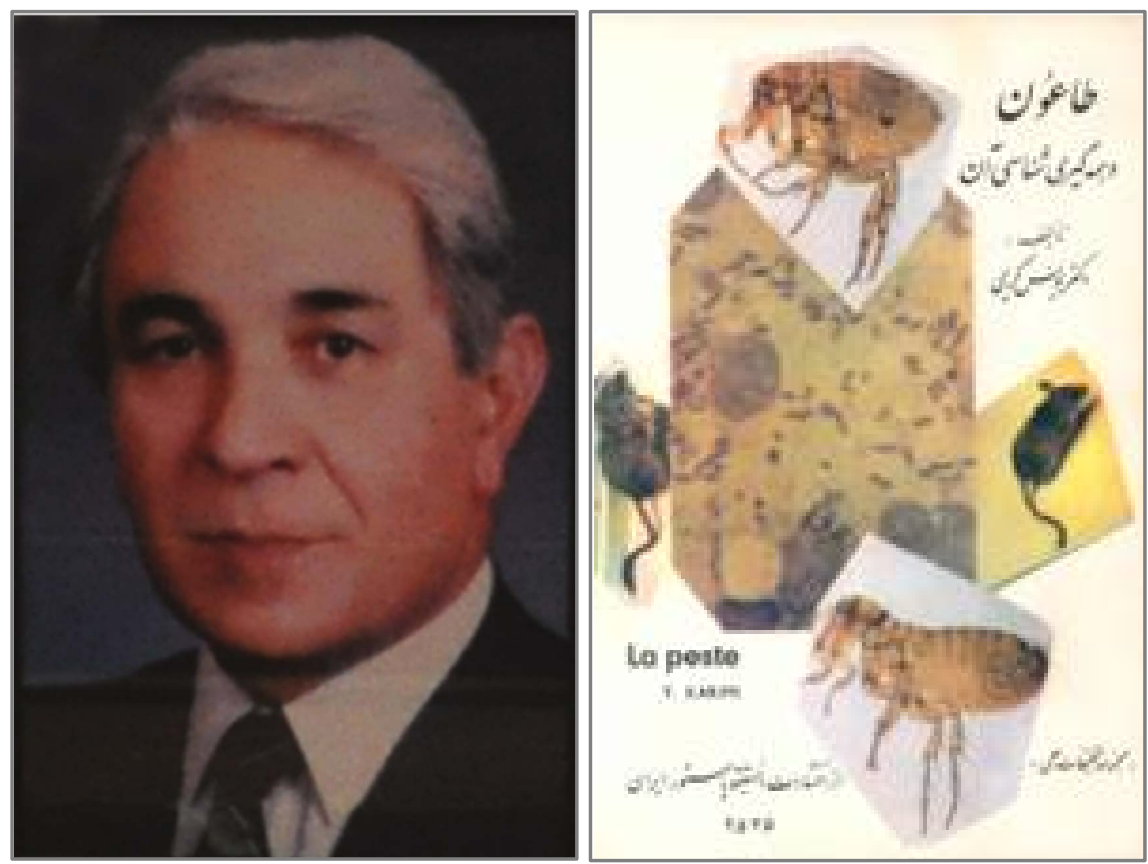

Figure 10. YounesKarimi an Iranian specialist of infective and parasitic diseases, and his medical work (right). 
On his return to Iran, he was employed at the Pasteur Institute of Iran and investigated various epidemic diseases, particularly the human plague. He studied this fatal disease for around 25 years in Iran includingKurdestan and Azarbaijan provinces as well as in Brazil and Zaire, as an expert of the World Health Organization (WHO). Between 1963 and 1978, Dr. Karimi published 16 original papers on the human plague in Iran in sound international journals, which included WHO publications (the list of papers and names of his colleagues are available at Pub Med). He also wrote a comprehensive Persian book entitled "Plague and its Epidemiology" which was published by the Pasteur Institute of Iran in 1977. His book contained the latest data at the time on plague endemic foci in the world and Iran, as well as valuable data on the species of rodents responsible for human plague outbreaks in Iran. Dr. Karimi died at the age 80 in Tehran and his memorial ceremony was held at the Pasteur Institute of Iran in 2009.

The Bacteriology Department of the Pasteur Institute of Iran was established in 1953 and was a pioneer in research on epidemic diseases, including the human plague. An international plague seminar was held at the Pasteur Institute of Iran in 1970.

In the 20th century, great outbreaks of the human plague with high mortality continued, especially in India. Despite the discovery of the etiologic agent of the human plague, the introduction of antibiotics for patients' treatment and worldwide hygienic improvement, outbreaks of the human plague continued during the last decades of the 20th century. Between 1980 and 1986, in total, 4522 cases from 17 countries (Iran was not included) were reported to the WHO. Of these patients, 431 died.

According to some experts, outbreaks of the human plague in the future are still possible due to the known and probable plague transmission foci in the world [15].

\subsubsection{The Highlights}

- Plague, a disease of rodents due to infection with Bacillus pestis, transmitted to man by rat-fleas, epizootic in rats invariably preceding epidemics [16]. In man the disease is characterized by enlargement of lymphatic glands (bubonic plague), severe prostration, a tendency to septicemia, and occasional involvement of lungs [17].

- The plague presented itself in three interrelated forms. The bubonic variant (the most common) derives its name from the swellings or buboes that appeared on a victim's neck, armpits or groin. These tumors could range in size from that of an egg to that of an apple. Although some survived the painful ordeal, the manifestation of these lesions usually signaled the victim had a life expectancy of up to a week. Infected fleas that attached themselves to rats and then to humans spread this bubonic type of the plague. A second variation-pneumonic plague-attacked the respiratory system and was spread by merely breathing the exhaled air of a victim. It was much more virulent 
than its bubonic cousin-life expectancy was measured in one or two days. Finally, the septicemic version of the disease attacked the blood system.

- Remnants of the generic makeup of plague bacteria have been found in thousands of victims of the Black Death and the major plague epidemics at the end of the Iron Age. The DNA analyses may predict the next plague outbreak.

- Bacterial DNA from the Black Death in teeth-Apollon.

- During the epidemic of plague one proposal to combat the disease was to float a ship of peeled onions down the Thames?

- Lazarettos were originally designed to house lepers well out of harms way. With decline of leprosy in Europe from around the 13th century, Lazarettos increasingly became requisitioned pest-houses in times of plague. In either case, their crucial function was to protect the rest of the population [18].

- A traditional protective costume worn by physician to protect the body from disease:

In Rome the doctors do appear, When to their patients they are called, In places by the plague aped,

Their hats and cloaks, of fashion new, Are made of oil cloth, dark of hue, Their caps with glasses are designed, Their bills with antidotes all lined, That foul some air may do no harm, Nor cause the doctor man alarm, The staff in hand must serve to show, Their noble trade where'er they go.

- The association of rats with bubonic plague had been known since Biblical times, and this man performed a public health service (bubonic plague's a form of plague in which is great swelling of the lymphatic glands, especially those in the groin.)

- Wigs became out of fusion "for nobody dare to buy hair for fear of the infection, that it and been cut off of the heads of people dead of the plague".

- Samuel Pepys has written that: "I was forced buy some roll tobacco to smell to and chaw-which took away the apprehension".

- Rats, long believed to be the scourge that brought the Black Death to 14thcentury Europe may not be the disease-bearing scoundrels we thought they were.

- Pandemic responsible for millions of deaths to a new furry menace: giant gerbils from Asia.

- Great gerbils, which are found in many parts of central Asia, can grow to adult sizes of about 15 - 20 centimeters in body length.

- The researchers say the findings offer an alternative explanation for how the pandemic, which peaked around 1347-1353, wiped out so many lives the following four centuries.

\section{- The evolution of plague bacteria:}

-The big question is where the plague bacterium comes from, whether the three plagues stem from the same bacterium, and how the plague bacterium survived between the outbreaks. Some people believe that the plagues at the end of 
the Iron Age and during the Middle Ages were two different diseases, but several studies show that they were the same disease.

- "The transitions between the three plague outbreaks are not completely clear. There was also an overlap between the second and the third outbreaks. Plague can completely vanish for decades, and then return," says Professor Kjetill S. Jakobsenof the Centre for Ecological and Evolutionary Synthesis (CEES), University of Oslo.

-The question is: in which circumstances does plague become pandemic and what determines the level of severity of the epidemic?

-"It is tempting to speculate whether the ecology of the locations in which the pandemics started played a role in their level of destruction. We can understand the serious pandemics in the past, present and future by looking at the link between climate conditions and plague dynamics," says Professor Nils Christian Stenseth, Chair of CEES.

- In the aftermath of the Civil War and the religious conflicts of the time, people were quick to point finger at whom or what they thought was to blame for plague.

Biologists at the University of Oslo are now making giant effort to identify the relationship between climate change, rat infestations, and the many major plague epidemics throughout history. The knowledge may be used to predict the next plague outbreak.

- Plague did not only occur in the Middle Ages. There are 2,000 cases of plague annually; most of them in Madagascar and Congo. Outside Africa, plague occurs in the deserts of North America and in large areas in Central Asia, in a wide belt from Georgia via Kazakhistan to China.

- The initial fourteenth century European event was called the Great Mortality by contemporary writers, and with, "became known as the Black Death".

- The disease has been popularly thought that the name came from a striking symptom of disease, called acral necrosis.

\subsubsection{Impact}

The Black Death had a huge impact the society. Fields went unplugged as the men who usually did this were victims of the disease. Harvests would not have been brought in as the manpower did not exist. Animals would have been lost as the people in a village would not have been around to tend them. Historians have traditionally regarded the Black Death as a leading factor in the breakup of the medieval world. Some historians have even dated the beginning of modern times from 1348. According to this view, the Black Death engendered a great shortage of labor and radically changed the European economy. Competition for workers increased. In order to keep their surviving peasants from leaving the land, feudal lords were forced to lower rents and to commute heavy payments in labor and in kind to payments in money; the last vestiges of serfdom and of manorial organization were thus swept away. The lords also tried to keep the peasants attached to the land by legislation, thus provoking peasant uprisings, such 
as the English peasants' revolt of 1381. Wages in the towns rose rapidly, though the efforts to control them also led to considerable social unrest. The calamities also bred a mass psychological depression and a morbid concern with death. These led in turn to dissatisfaction with the established church and were factors in the spread of heresies. Thus, on every level, intellectual as well as economic, the Black Death undermined medieval system and prepared the way for the modern world.

Many of these changes, however, can no longer be considered the direct impacts of the Black Death. The decline of serfdom, for example, and the breakup of the manor were processes that in most areas of Europe had begun long before 1348. Moreover, the Black Death was only one aspect of a general European crisis, particularly pronounced over the century 1350-1450. This crisis was caused not only by the plague, but also by the period's many wars, frequent crop failures, famines, and perhaps by resultant malnutrition, which paved the way for plague [19].

Plague and syphilis challenged both the health of population and the systems of healing that Europeans had inherited from their medieval predecessors, although neither disease responded particularly well to contemporary medical techniques, both helped to encourage the foundation of hospitals, the development of elaborate public-health regulations, as Boccaccio suggested, and the creation of new institutions such as college of physicians, dedicated to protecting the practice and reputation of the higher levels of the medical profession [20].

Plague alone, reduced the world population from an estimated 450 million down to 350 - 375 million in the 14 th century. The world population as a whole did not recover to pre-plague levels until the 17 th century. It recurred occasionally in Europe until 19th century.

The plague also created a series of religious, social, and economic upheavals, which had profound effects on the course of European history [21].

Note: Epidemic: An outbreak of an infectious disease spreading widely among people at the same time in any region. Pandemhc: Of an epidemic occurring over a wide area such as a country or a continent. Although the plague is prevalent in South-East Asia, but it will never be a major problem again, as antibiotics destroy the bacterium, provided they are taken as soon as they are recognized.

\section{References}

[1] Cochrane, J. (1996) An Illustrated History of Medicine. Tiger Book International, London, 6 .

[2] Humphery, E. (1915) Encyclopedia International. Vol. 14, Grolier, New York, 232.

[3] General Plague of Vienna-Wikipedia, the Free Encyclopedia; Jennifer Cochrane (1996) An Illustrated History of Medicine, 81.

[4] (1975) Encyclopedia International. Vol. 3, 91.

[5] Boccaccio, G. (1975) The Decameron. Vol. 1, Translated by Richard Aldington, Illustrated by Jean de Bosschere (1930); Gottfried, Robert, the Black Death (1983).

[6] Edward, H. (1975) Encyclopedia International. Vol. 11, 71. 
[7] Edward, H. (1975) Encyclopedia International. Vol. 11, 49.

[8] (1955) Our Wonderful World. Spencer Press, Inc., 181-182.

[9] Porter, R. (1998) The Cambridge Illustrated History of Medicine. Cambridge University Press, Cambridge.

[10] https://en.wikipedia.org/wiki/1629-31-italian/plague

[11] https://en.wikipedia.org/wiki/the-betrothed-(manzoni-novel\#chapter-31.E2.80.6333 :-plague

[12] Great Plague of Vienna-Wikipedia, the Free Encyclopedia.

[13] Great Plague of Marseille. https://en.wikipedia.org/wiki/Great-Plague-of-Marseille

[14] Moscow Plague Riot of 1771-Wikipedia, the Free Encyclopedia.

[15] History of Plague in Iran. http://www.ams.ac.ir/

[16] List of Epidemics. https://en.wikipedia.org/wiki/list-ofepidemics

[17] Collocott, T.C.C. (1982) Chambers Dictionary of Science and Technology. Vol. 2, W\&R Chambers, Edinburgh, 899.

[18] Loudan, I. (1997) Western Medicine an Illustrated History. Oxford University Press, Oxford, 210.

[19] Edward, H. (1975) Encyclopedia International. Vol. 3, 48.

[20] Porter, R. (1998) The Cambridge Illustrated History of Medicine. Cambridge University Press, Cambridge, 67.

[21] Black Death-Wikipedia, the Free Encyclopedia.

Submit or recommend next manuscript to OALib Journal and we will provide best service for you:

- Publication frequency: Monthly

- 9 subject areas of science, technology and medicine

- Fair and rigorous peer-review system

- Fast publication process

- Article promotion in various social networking sites (LinkedIn, Facebook, Twitter, etc.)

- Maximum dissemination of your research work

Submit Your Paper Online: Click Here to Submit

Or Contact service@oalib.com 